УДК 321; 323.2

ДАХИН Андрей Васильевич - доктор философских наук, профессор кафедры истории и теории государства и права Нижегородского института управления - филиала Российской академии народного хозяйства и государственной службы при Президенте РФ (603950, Россия, г. Нижний Новгород, nр-кт Гагарина, 46; nn9222@rambler.ru)

АВДОНИН Владимир Сергеевич - доктор политических наук, ведущий научный сотрудник Института научной информации по общественным наукам РАН (117218, Россия, г. Москва, ул. Д. Ульянова, 3; avdoninvla@mail.ru

\title{
ОТЕЧЕСТВЕННАЯ ПОЛИТИЧЕСКАЯ РЕГИОНАЛИСТИКА И РЕГИОНОВЕДЕНИЕ: ТРАНЗИТ ПРЕДСТАВЛЕНИЙ О РЕГИОНАЛЬНОМ ПОЛИТИЧЕСКОМ ПРОЦЕССЕ В СВЕТЕ ВОПРОСОВ МЕЖДУНАРОДНЫХ СВЯЗЕЙ РЕГИОНА И МУНИЦИПАЛЬНОЙ ПОЛИТИКИ
}

\begin{abstract}
Аннотация. Статья представляет собой обзор дискуссии, посвященной 30-летию отечественной политической регионалистики, состоявшейся в Нижнем Новгороде 27 мая 2021 г. В проблемном поле материалов сочетаются собственный контент политической регионалистики, регионоведения, а также контент исследований муниципальной политики и контент международных отношений, завязанный на исследования международных связей региона. Основное внимание уделяется тому, что региональная политика как достаточно обособленное системное образование как бы зажата между внутренними подсистемами (муниципалитеты) и внешними для нее надсистемами (федеральная политика России, международные отношения). В качестве теоретической формы целостного описания структуры «подсистемы - система - надсистемы» рассматривается концепция региональной стратификации политического пространства, которая позволяет конкретизировать диапазоны и формы связи «регион - муниципалитет», «регион - федеральный центр», «регион - акторы международных отношений» в контексте понятия о единой системе публичной власти в России.
\end{abstract}

Ключевые слова: политическая регионалистика, региональная стратификация политического пространства, региональная публичная власть, муниципальная публичная власть, потенциал муниципальной власти, региональный политический режим, политическое лидерство, региональная политическая элита

Д искуссия, посвященная 30-летию отечественной политической регионалистики, состоялась в рамках круглого стола, проведенного на площадке Нижегородского института управления - филиала РАНХиГС в рамках XVI Международного симпозиума «Антропный принцип развития, социальное государство, урбанизация: Диалог мировоззрений» (Нижний Новгород, 27 мая, 2021 г.). Проблемное поле круглого стола очерчивает новые контуры политической регионалистики России, где собственный контент этой субдисциплины и регионоведения сочетается с контентом исследований муниципальной политики, а также с контентом международных отношений (municipal public power), международных связей региона. Доклады участников дискуссии, соответственно, отражают отдельные аспекты политической жизни российского региона.

Доктор социологических наук, главный научный сотрудник Института социологии ФНИСЦ РАН $\boldsymbol{A}$.E. Чирикова (Москва) в докладе «Муниципальная власть в России: динамика перемен» на основе эмпирического исследования 
в 5 малых российских городах проанализировала проблемное поле малых российских городов, рассмотрела вопрос об уровне мотивации глав городов и их команд. Приводится пример одного из городов, опыт которого позволяет дать утвердительный ответ на вопрос: «Возможны ли сегодня перемены в муниципальной власти?» Характеризуя состояние исследований муниципальных политических территорий, А.Е. Чирикова показала, что муниципальная власть в России, ее устройство и ключевые акторы на протяжении двух последних десятилетий являются предметом анализа и профессиональных дискуссий в области региональных исследований. Начиная с экономистов и социологов и заканчивая политическими регионалистами и географами, различные группы профессионалов анализируют процессы, протекающие в городах с использованием различных теоретических схем и подходов, стремясь определить механизмы и формы связи муниципалитета и региона (субъекта федерации).

Большой вклад в развитие темы местного самоуправления сделал Р. Туровский и его соавторы [Туровский 2015а; Туровский, Васеленко 2019] и др. Работы не только раскрывают теоретические подходы к местному самоуправлению, но и содержат интересный эмпирический материал, который существенно расширяет наши представления о том, что происходит на этом уровне власти. Развернутые эмпирические исследования недавних лет представлены работами В. Гельмана, С. Рыженкова и др., О. Моляренко, А. Чириковой, В. Ледяева и др. [Гельман и др. 2002; Моляренко 2021; Чирикова, Ледяев 2017; 2020]. Большое внимание уделяется изучению городских политических режимов. В этом направлении работают В. Ледяев [Ледяев 2012] и другие исследователи. Все исследования позволяют описать многие городские процессы в рамках взаимодействия (конфликтности) местных элит и форм их координации между собой и с системами власти регионов.

Характеризуя полученные эмпирические данные, А.Е. Чирикова отметила, что проведенное исследование позволило убедиться: комплекс проблем малых городов 5-8 лет назад и сегодня практически неизменен. Как и вчера, сегодня элиты настойчиво говорят о том, что муниципальная власть в России фактически не имеет ресурсов для развития - ни финансовых, ни профессиональных. Среди наиболее часто формулируемых локальными элитами проблем во всех 5 исследованных городах как вчера, так и сегодня остается проблема перераспределения налоговых источников пополнения бюджета. Сегодня муниципалитеты большую часть собираемых средств отдают в вышестоящие бюджеты, тратя оставшиеся ресурсы на выполнение соцобязательств и лишаясь возможности развиваться. Именно поэтому одного НДФЛ, по их мнению, явно недостаточно для реализации стратегии развития в муниципалитетах. Помимо налоговых проблем, элиты, принявшие участие в исследовании, отмечают и другие точки напряжения местной власти. Среди них наиболее часто звучат такие проблемы, как:

- слабый кадровый потенциал, низкая работоспособность глав городов и их команд, инертность института муниципальной власти, бюрократизация, низкая скорость принятия решений;

- развитость неформальных практик во взаимодействии с бизнесом и населением;

- эффект эмоционального выгорания сотрудников;

- высокая неудовлетворенность, с одной стороны, профессионализмом глав городов, с другой - квалификацией членов их команд;

- напряженность в отношениях с региональной властью, неудовлетворенность действиями федеральной власти. 
Напряженные отношения с региональной властью (в четырех из семи исследованных городов) вызваны прежде всего тем, что муниципалы недовольны требованием беспрекословного подчинения губернаторам, которые не учитывают особенности ситуации на местах. Регионалы, со своей стороны, также не удовлетворены существующими отношениями с муниципалитетами, полагая, что муниципальная власть могла бы отказаться от излишней самостоятельности, демонстрируя больший пиетет перед государственной властью, тем более что жесткий контроль чаще всего вызван неэффективностью решений, принимаемых органами местного самоуправления на фоне низкого уровня дисциплины в структурах местного самоуправления. Решение этой проблемной ситуации видится автору доклада в опыте одного из исследованных городов $($ город $G)$ : муниципальная власть способна развиваться, и условием для этого является наличие сильного лидера, эффективной команды последователей и стратегические партнеры, способные действовать в унисон с местной властью, а не противостоять ей. Важным условием является также налаженное взаимодействие с региональной властью. Исследование показывает, что основное условие участия любой коммерческой компании в городской политике - это наличие людей со стратегическим мышлением в руководстве градообразующего предприятия, идентифицирующих себя с городом. Дилемма отношений (взаимодействие с властью или противодействие ей) определяется удовлетворенностью/неудовлетворенностью главой городской администрации и его командой. В качестве позитивного фактора А.Е. Чирикова отмечает перемены спроса со стороны населения к власти.

Доктор философских наук, профессор НИУ РАНХиГС А.B. Дахин (Нижний Новгород) в докладе на тему «Региональная стратификация системы публичной власти: транзит отношений “регион” - “муниципалитет” - "intermestic policy”" отметил, что современная российская политическая регионалистика формировалась в качестве продолжения советской политической и экономической географии [Гельман 2001], а с 1991 г. - под влиянием западной политической науки. Становление отечественной политической регионалистики в качестве субдисциплины российской политической науки продолжается в настоящее время. Анализ материалов ежегодных конференций Российской ассоциации политической науки (РАПН) позволяет отмечать активную диверсификацию предметной области политической регионалистики - от региональных выборов и региональных политических процессов исследователи переходят к изучению региональных политических режимов, региональных политических элит, региональных политических культур, региональных публичных политик, региональных state capacities, региональных политических институтов, партийной инфраструктуры, идентичности, региональной политики памяти и пр. Здесь видится своеобразный вызов для политической регионалистики, которая стоит перед этапом, когда нужно переосмысливать и доосмысливать свой дисциплинарный контур, переосмысливать, концептуально усиливать основания собственной внутренней целостности. По мнению А.В. Дахина, введение в Конституцию РФ понятия «единая система публичной власти» и положения о том, что «органы местного самоуправления и органы государственной власти входят в единую систему публичной власти в Российской Федерации», а также появление понятия «федеральные территории» (ст. 1., п. 1(а), п. 44(г), п. 45(в) $)^{1}$ в новом свете актуализируют проблематику статуса систем муници-

\footnotetext{
1 Закон РФ о поправке к Конституции РФ от 14.03.2020 N 1-ФКЗ «О совершенствовании регулирования отдельных вопросов организации и функционирования публичной власти». Доступ: http://www.consultant.ru/document/cons_doc_LAW_346019/(проверено 08.11.2021).
} 
пальной и региональной власти в России. А понятие intermestic policy [Putnam 1988] вносит в рамку концептуального описания этой политической среды также и фактор международного влияния. Сложившаяся дискуссия по этой тематике, если брать широкие концептуальные рамки, колеблется в границах между «партнерской моделью» и моделью «административной опеки», причем в 1990-х гг. дискурс муниципальной политологии был смещен в сторону первой с акцентом на становлении «местной автономии», а в нулевых - в сторону второй модели, с акцентом на укреплении «вертикали власти» и «субнационального авторитаризма» [Туровский 2015б: 224, 232, 233]. Сходная проблема имеет место также и на более высоком уровне региональной стратификации политического пространства - там, где действуют независимые государства и международные процессы и используется понятие intermestic policy.

Анализ регионально-муниципальной проблематики требует определенного переосмысления понятий «политический режим» и «потенциал государства» [Gel'man 2008], которые в проекции на систему региональной стратификации политического пространства трансформируются в понятия «региональный/муниципальный политический режим» И «собственный потенциал региональной/муниципальной власти». Для обоснования муниципальной политики в качестве самостоятельной субдисциплины отечественной политической науки необходимо ответить на вопрос: обладают ли муниципалитеты собственным потенциалом публичной власти? Принимая во внимание исследования Э. Остром о роли муниципальных сообществ в решении местных проблем пользователей «общими ресурсами» [Остром 2010], можно заключить, что системы муниципального самоуправления могут обладать собственным, неотчуждаемым потенциалом публичной власти, который, однако, в одних случаях может быть мобилизован и активизирован, а в других случаях - заброшен, дискриминирован в пользу иных ресурсов политического влияния.

Устойчивость всей системы публичной власти России в обсуждаемом ракурсе во многом зависит от состояния «муниципальной стопы» региональной власти, которая сводится к структуре и ресурсам собственного потенциала муниципальной публичной власти. А.В. Дахин определил элементы собственного потенциала муниципальной публичной власти: они связаны с отношением муниципальных сообществ к территории своего проживания, с «общинными» и гражданскими формами локальной солидарности внутри муниципального сообщества, с локальными формами поддержания социального порядка, а также с материально-хозяйственными и финансовыми ресурсами, находящимися в собственности муниципалитета или граждан - резидентов муниципальной территории. Сильные «общинная» и гражданская формы локальной солидарности создают сильную «муниципальную стопу» публичной власти, факт наличия которой говорит о том, что собственные ресурсы муниципалитета действуют в качестве части неотчуждаемого потенциала муниципальной публичной власти. Онтологической основой этого потенциала (municipal capacities) выступают активное состояние структур социально-исторической памяти и идентичности локального сообщества. Примеры высокого уровня «общинной» солидарности дают локальные этнокультурные и конфессиональные сообщества муниципальных территорий, общины народов Севера России, республик Северного Кавказа и др. Примеры высокого уровня гражданской солидарности дают отдельные муниципалитеты России, где действуют живые товарищества общественного самоуправления (ТОСы), реализуются программы партисипаторного бюджетирования (Череповец и т.п.) и пр. В этом контексте содержательную рамку понятия «муниципальный политический 
режим», содержание которого обычно сводилось к описанию механизмов представительной демократии, необходимо расширить за счет включения в поле зрения механизмов совещательной демократии (deliberative democracy) и партисипаторной демократии (participatory democracy). Расширение обусловлено тем, что интеграция названных выше ресурсов собственного потенциала муниципальной публичной власти возможна, прежде всего, посредством механизмов совещательной и партисипаторной демократии. В свете нашего подхода муниципальная политика «сливается» с предметом отечественной внутриполитической регионалистики, если официальные власти дискриминируют перечисленные выше собственные ресурсы муниципальной публичной власти и полностью встраиваются в «вертикаль власти». Если же официальные муниципальные чиновники культивируют и активизируют собственные ресурсы муниципальной публичной власти в поле своего муниципально-гражданского партнерства, то муниципальная политика определенно будет иметь особенное политическое лицо и попадет в предметную область субдисциплины «муниципальная политика».

Дополнительные особенности муниципальной политико-экономической среды связаны с тем, что крупные города России (областные центры и т.п.) интегрированы в поле международных отношений в регистре экономических, культурных, образовательных, экологических, научных и др. контактов. Поэтому на территории муниципалитета (и субъекта федерации) действует не только «вертикаль власти», но и «вертикаль влияния иностранных акторов социально-экономической активности», участие которых создает структуру, которая может стать политической доминантой и описывается в терминах intermestic policy. Если в поле отношений «субъект федерации - муниципалитет» предметом исследования выступает баланс внутренних муниципальных ресурсов публичной власти и внешних (для муниципалитета) ресурсов власти субъекта федерации, то в поле концепции intermestic policy речь идет о балансе внешнеполитических и внутриполитических ресурсов власти, который проецируется также и на муниципальный уровень. Эта сложная многоуровневая структура отношений может быть описана в свете концепции региональной стратификации политического пространства [Дахин 2015a; 2015б] и представлена в виде «колонны стратификации», у которой есть «муниципальная стопа», региональный, межрегиональный, общероссийский/страновой и международный уровни публичной власти. Основной предмет исследования отечественной политической регионалистики, находясь в теле «колонны стратификации» среди иных территориально определенных уровней публичной власти, собирает в своем политическом пространстве элементы политических отношений с ними. Комплексный анализ предполагает, соответственно, инструментарий, который позволяет изучать весь спектр этих отношений - от регионально-муниципальных до международных.

Доктор политических наук, профессор ИНИОН РАН В.А. Авдонин (Москва) в докладе на тему «Возможности и проблемы региональных политических исследований» в основном сосредоточился на проблеме растущей дифференциации и прогрессирующей сегментации исследовательского поля политической регионалистики в современной России. Сама по себе эта проблема не является принципиально новой и необычной. Уже на заре отечественной политической регионалистики, в 1990-е гг, авторы отмечали ее сложносоставной, а в известном смысле - и разнородный характер. В дальнейшем, в нулевые годы, внимание к предметно-тематической и методологической дифференциации и сегментации политической регионалистики сохранялось. Стали подчеркиваться ее междисциплинарный характер, слабая интеграция пред- 
метного поля, ограниченная концептуализация, проблемы взаимодействия с практикой и др. Тем не менее определенные надежды на интеграцию этого поля имели место [Авдонин, Баранов, Дахин 2008; Дахин 2016]. Но, как показало дальнейшее развитие, подлинной интеграции не получилось.

Далее докладчик выделил и охарактеризовал три наиболее заметных расходящихся сегмента исследовательского поля российской политической регионалистики. Первый сегмент он условно определил как политико-управленческий. В какой-то мере он наследует той части политической регионалистики 1990-х - начала нулевых, которую называли «исследованием отношений центра и регионов» и которая включала много политических аспектов, достаточно актуальных в период активной федерализации и регионализации российской политики. Сегодня это направление сохранилось и проявляет себя в публикационной активности и в исследовательских проектах [Информационный бюллетень... 2015-2019]. Но в нем заметна тенденция к сближению с подходами управленческих и юридических наук. Собственно политическая проблематика, связанная с борьбой за власть политических акторов, их ресурсами, конфликтами и компромиссами, политической институционализацией, формированием политических режимов, отходит на второй план. При резком усилении центральной власти и сокращении автономии регионов проблематика формирования там сколько-нибудь самостоятельной политики, анализа ее условий, акторов, стратегий и институтов потеряла актуальность. Построение «властной вертикали» перевело отношения центра с регионами в план административно-управленческих взаимодействий, сопровождающихся теми или иными проблемами и эффектами, характерными для неполитических управленческих систем. Вслед за процессами «вертикализации» двигался и анализ, включавший все больше управленческих категорий, схем и моделей, более адекватных сложившимся реалиям. Концептуальный аппарат политологии отходил здесь на второй план. Федерализм потерял политическое измерение и стал все больше сводиться к процессам, обсуждение которых часто идет на формально-юридическом и бюрократическом языке, больше доступном юристам и бюрократам.

Второй сегмент этого исследовательского поля можно было бы назвать политико-территориальным, или политико-пространственным. И он тоже имеет свою историю в отечественной политической регионалистике. Главной чертой этого направления было приоритетное рассмотрение территориального фактора в политике, и в политической регионалистике это давало большой эффект [Elazar 1999]. Оно шло дальше формальных территориально-политических единиц различного масштаба (субъектов федерации, муниципальных образований, федеральных округов) и могло рассматривать самые разные территориальные образования - от небольших местностей и ландшафтов до крупных макрорегионов, как географических, так и культурных, экономических, исторических и т.д. Переход к политике в такого рода исследованиях обычно происходит через рассмотрение территориальных сообществ, которые формируются на определенной территории и в той или иной степени проявляют себя политически. Для исследования такой политики характерно большее внимание к ее территориально-географической, социально-экономической, культурной, этноконфессиональной и прочей специфике, чем к системным общеполитическим условиям, процессам и проблемам.

Сегодня активность этого направления сохраняется и даже интенсифицируется. Прежде всего, его характеризует внимание к специфичности, связанной с многообразием влияющих на политику факторов. Особенно заметны здесь территориальные и этноконфессиональные факторы. Растет объем исследова- 
ний по регионам с этнической и этноконфессиональной спецификой (республики, полиэтнические регионы, регионы с растущей этнической миграцией), с территориальной спецификой (приграничные регионы, регионы Юга, Севера, Дальнего Востока, Арктики и др.). К ним примыкают исследования и по специфике региональной культуры, идентичности, истории и исторической памяти, региональным брендам и т.д. Часто эти исследования весьма далеки от собственно политологического анализа и рассматривают лишь ту или иную степень влияния этих разнообразных особенностей на политику как региональной власти, так и центра. Сегодня политизация этих особенностей в регионах находится под подозрением и блокируется центром. Вытеснение политики происходит не только из региональных органов власти, где она заменяется административно-управленческими практиками, но и из региональных сообществ, где ее заменяют этнокультурные и территориально-культурные практики неполитического характера.

Третий сегмент можно назвать собственно политологическим. Он тоже опирается на определенную традицию в отечественных исследованиях. Важной вехой его развития было освоение ключевых категорий политической науки, таких как политическая система, политический процесс, политический режим. Практика активной федерализации и регионализации в российской политике того периода демонстрировала эффективность такого анализа. Концепция регионального политического режима, возникшая в тот период, позволила продуктивно интегрировать знания основных областей развивавшихся тогда эмпирических исследований (исследования региональных выборов, региональных элит, отношений «центр - регионы»). Появилась возможность режимной типологизации складывающихся в России региональных политий. На этой основе был выполнен целый ряд интересных исследований [Россия регионов... 2000; Кузьмин, Мелвин, Нечаев 2002; Туровский 2009].

Жесткая централизация в последующие годы фактически ликвидировала региональную автономию, что способствовало ревизии концептуального аппарата российской политической регионалистики и, в частности, ослаблению в ней роли политологических категорий, таких как региональный политический режим и др. По существу, это стимулировало и те процессы сегментации, о которых сказано выше. На и без того слабо консолидированном исследовательском поле политической регионалистики усилился дрейф от политического, в одном случае, в сторону управленческо-административного и формально-юридического, а в другом - в сторону территориально, социально и культурно специфического.

В заключение докладчик высказал соображения о развитии исследований того направления, которое он назвал политологическим. Они могут быть связаны с разработкой и применением в политической регионалистике интегрального концепта «региональный политический режим», который позволяет объединять элитные и массовые уровни политики, анализировать виды политических акторов, их ресурсов и стратегий, характер формальных и неформальных институтов и т.д., выходя при этом на базовую дихотомию мира современной политики - его деление на демократические и недемократические политические режимы. В современных условиях режимный подход будет в основном означать приоритетное внимание к исследованию многообразия авторитарных характеристик региональной политики.

Доктор политических наук, профессор СГУ им. П.А. Сорокина В.A. Ковалев (Сыктывкар) в докладе на тему «“Узкий коридор” для регионов» рассмотрел концепцию «узкого коридора» - равновесия между сильным государством и сильным обществом Дарона Аджемоглу и Джеймса Робинсона. По его 
мнению, для успеха региональных реформ в России должен быть пройден «узкий коридор» между центром и субъектами федерации. Это невозможно без социально-политической активности на местах и перераспределения ресурсов и полномочий публичной власти в пользу регионов и местного самоуправления. Отталкиваясь от Левиафана Т. Гоббса и отметив, что решающее значение для развития политической регионалистики имеет, конечно, состояние региональной политики, профессор Ковалев показал, что для специалистов и для заинтересованных лиц важно сохранить крупицы знания, добытые немалой ценой, - извлечь толику опыта из сложных и драматичных процессов в конкретном государстве. Чрезвычайно высокая концентрация ресурсов в федеральном центре власти способствует тенденции к возникновению такого политического образования, которое Гарольд Лассуэлл в свое время называл «гарнизонным государством», а оно бывает очень склонно к военно-авантюрной геополитике. И наоборот, при прочих равных условиях, распределение ресурсов на местах дает возможность тратить деньги на текущие и очевидно актуальные цели, повышая качество и уровень жизни населения. Разумеется, нужно учитывать фактор коррупции и другие возможные неблагоприятные обстоятельства, но их надо иметь в виду в любом случае. Таким образом, нахождение более оптимального и справедливого баланса между центральной и региональной властью, между государством и самоуправлением местных сообществ - это не только вопрос региональной политики, но и актуальная проблема национальной безопасности. Поискам ответов на вопрос о балансе власти и ресурсов может способствовать концепция «узкого коридора», предложенная Дароном Аджемоглу и Джеймсом Робинсоном в их недавно вышедшей и переведенной книге [Аджемоглу, Робинсон 2001]. Напомним, что эти известные авторы свой немалый труд посвятили доказательству и иллюстрации тезиса, согласно которому движение к обществу, которое будет богатым, безопасным и демократическим, возможно лишь по узкому коридору, который создается сильным государством и сильным обществом, которые уравновешивают, контролируют и сдерживают друг друга. Подход Аджемоглу и Робинсона применительно к России может иметь и свою региональную проекцию, когда баланс ищется не только между правительством и населением, но и между центром и периферией по формуле: «сильный центр - сильные регионы». Однако добиться такого баланса в условиях крайне разнородного потенциала и уровня развития территорий федерации едва ли не сложнее, чем воплотить на практике демократический метод (в понимании Й. Шумпетера). Автор данного доклада уже однажды пытался (может быть, несколько хаотично) проанализировать эту проблему, проводя сравнительный анализ издержек федерализма и административной вертикали в РФ в «лихие девяностые» и нулевые годы [Ковалев 2018]. Серьезнейшим вызовом для отечественных регионалистов (и, разумеется, для тех, кто будет в будущем, после выхода из нынешнего тупика, проводить региональную политику) является поиск идей, как эти противоречия преодолеть, избежав при этом распада страны. Разумеется, реальное и законное воплощение принципов демократии и федерализма очень важны, и такие предложения продолжают вызывать надежду в сознании демократически настроенных граждан. Но в условиях крайней разнородности субъектов федерации и дотационности подавляющего большинства из них демократия и федерализм являются необходимым, но далеко не достаточным условием сохранения и развития отечественной политии. Разумеется, наряду с регионами, есть еще уровень муниципальный. В принципе было бы очень хорошо совершить перераспределительный маневр в его пользу, предоставив больше 
ресурсов в распоряжение МСУ. Кроме всего прочего, это позволило бы осуществлять массовое воспитание населения в духе гражданской культуры и политического участия. (Поскольку «самая близкая к народу власть» занимается наиболее и животрепешущими и понятными для рядовых граждан проблемами, постольку «научить демократии» без соответствующей практики невозможно.) Напомним, что именно социальная апатия и отсутствие элементарных навыков гражданского участия были причиной слабости социума, не удержали транзит в «узком коридоре» между властью и населением, что и предопределило очередной пароксизм «сталинизма» со стороны государства. В заключение профессор В.А. Ковалев сделал вывод: задачей представителей политической регионалистики как субдисциплины политической науки является теперь не приумножение диссертационной схоластики и т.П., а напряженный поиск возможностей возрождения региональной и местной политики в нашей стране, внимательное описание, изучение и поддержка тех ростков, которые могут здесь появиться.

Доктор политических наук, профессор Нижегородского государственного университета им. Н.И. Лобачевского М.A. Казаков (Нижний Новгород) в докладе на тему «Политическая регионалистика: лидерский фактор в трансформации элит региона» продолжил обсуждение вопросов о роли политического лидерства, начатых А.Е. Чириковой. Изучение региональных элит было и остается в ней ведущим направлением. Его особую значимость иллюстрирует сегодня включенность в профессиональную среду, сферу влияния и ответственное исполнение функции управления, распределенной между элитами и выдвинутыми центром на роль лидеров регионов фигурами. Проблемы их взаимодействия в процессах развития современной России актуальны. Ныне это даже вопросы не столько к механизмам согласия, компромисса или «навязанного доминирования», сколько к эффективности деятельности выделенных акторов относительно заявленных приоритетов, а значит к ресурсам и способности решения государственных задач на уровне субъектов РФ. Одной из предпосылок к чему является наличие у их глав как лидеров и руководителей статусных, организационных, инструментальных и иных возможностей находить и осуществлять контроль над ресурсами; способностей к взаимодействию: между собой, последователями, элитами, населением, центром в режиме перманентной работы по выстраиванию коммуникаций и утверждению своей дееспособности. В постсоветской трансформации региональных элит данный фактор - существенное обстоятельство их преобразования и консолидации. Его возникновение в 1990-е гг. стало необходимым и реальным в связке с трендом открытости общества, власти, политики, а запрос на снижение уровня неопределенности потребовал институционализации политической элиты в центре и на местах. Ее принято определять как «устойчивую общность с глубокими связями входящих в нее людей, имеющих общие интересы и доступ к рычагам реальной власти и экономике» [Исаев 2013]. Категории политических элит и политического лидерства тесно связаны и соотносятся друг с другом не только в теории, но и на уровнях практики. Помимо социального профиля, способов рекрутирования, карьеры, за действиями «лиц, занимающих срединные ступени власти и влияния» [Василевски 2009: 12], стоят определенные системы взглядов и ценностей. По мнению В.А. Ковалева, «произошедший в “нулевые годы” отказ от реального, хотя и очень болезненного выстраивания политических институтов, в том числе на уровне регионов, привел к существенному сокращению экономических, политических и иных возможностей губернаторского корпуса... для реагирования на ситуацию в условиях вероятного обострения кри- 
зиса... Те, кто контролирует сейчас российскую политическую систему, просто не могут (в силу императива собственного сохранения, комфорта власти и доступа к сверхдоходам) пойти на усложнение системы» [Ковалев 2016: 90]. Возвращение губернаторских выборов дало повод экспертам активизировать дискурс о возрастающей значимости идеологии модернизации, смещенный во влиянии как на формирование стратегий развития страны и регионов [Казаков, Лысцев 2013: 5], так и на сопутствующие им технологии и онлайнплощадки. В конечном счете, за их созданием и выполнением стоят люди, и прежде всего лидеры, способные своевременно принимать адекватные происходящим изменениям управленческие решения. По мере подвижек в сознании, сближения позиций естественным выглядит и смещение акцентов в практиках на местах - от противоборства лидеров регионов и элит к согласованию идей, подходов, организационных схем развития как между ними, так и между региональными властями с институтами гражданского общества. Ряд исследователей в связи с этим, наряду с лидерским фактором, стали предлагать шире использовать понятие лидерского капитала, основанного на компетентности, моральности лидера, его способности к выбору правильного решения социальных проблем [Renshon 2000: 200]. В ходе доклада профессор Казаков рассматривал опыт Нижегородской области. В частности, он показал, что характер взаимодействия Г.С. Никитина с элитами региона можно охарактеризовать как более разностороннее, многовекторное и инновационное (что сразу проявилось в борьбе с коронавирусом), нежели у его предшественников. Он соответствует как мировой тенденции (интеллектуализация сфер современного социума), так и национальной (согласованная командная работа на стратегических направлениях). Это подтверждается не только диверсификацией управленческой деятельности, подчеркивающей изменение привычных форм политической жизни, но и конкретной практикой выстраивания губернатором, его окружением системы публичных общественных отношений в Нижегородской области с помощью новых методов и технологий, адекватных целям развития. В заключение М.А. Казаков сделал вывод, что ответы на вызовы отечественной региональной политики могли бы быть кратно результативнее, если бы лидерство в регионах было более дальновидным. Лидерство востребовано в качестве субъектной силы, направляющей региональную социально-политическую кооперацию и мобилизацию. При продуктивном сотрудничестве глав регионов с элитами в рамках единой государственной политики данное взаимодействие - залог не только партнерских отношений между ними, но и отношений региональных элит с федеральным центром.

Доктор исторических наук, профессор Нижегородского государственного лингвистического университета им. Н.А. Добролюбова О.Н. Сенюткина (Нижний Новгород) представила доклад на тему «Пересечение отечественной регионалистики и зарубежного регионоведения», в котором рассмотрела взаимодействие отечественной регионалистики как составляющей научного политологического знания и зарубежного регионоведения как направления образовательной деятельности высшего учебного заведения. Тенденции пересечения того и другого рассматриваются на примере Нижегородского государственного лингвистического университета им. Н.А. Добролюбова (НГЛУ) начала 2010-х гг. Профессор Сенюткина напомнила, что 2010-е гг. (20102019 гг.) - это десятилетие, которое заставило некоторых специалистов рассуждать о начале новой «холодной войны» из-за политического конфликта США и их союзников с Россией и Китаем. Отсюда логично большее внимание российского руководства к Востоку, в частности к Китаю [Иванов 2017]. 
Еще один фактор влияния - взаимодействие РФ и КНР. Третий значимый фактор, влиявший на необходимость развития зарубежного регионоведения, - это значимость укрепления отношений с ближним восточным соседом через просветительскую и образовательную деятельность. Переходя от вопросов необходимости программы зарубежного регионоведения к вопросам возможностей НГЛУ, О.В. Сенюткина отметила открытие Института Конфуция в Нижнем Новгороде, которое состоялось 06.06.2011. По сути, это открытие стало своеобразным толчком к тому, чтобы развернуть направление зарубежного регионоведения. Кафедра истории проявила заинтересованность и готовность к этому. К тому же в 1990-х гг. на кафедре был накоплен опыт преподавания курса «История цивилизаций», в котором уделялось внимание и китайской истории. К имеющимся возможностям можно отнести и тот факт, что отечественная регионалистика к началу 2010-х гг. прошла серьезный путь. В одной из статей А.В. Дахина были охарактеризованы основные этапы становления внутриполитической регионалистики в России в тесной увязке с политическими процессами. В этой научной статье, опубликованной в журнале «Политическая наука» (2016 г.), был сделан подробный историографический анализ пути становления развития как власти РФ, так и привязанной к ней внутриполитической регионалистики. По мнению автора, отечественная регионалистика, в частности политическая, к 2010-м гг. уже прошла серьезный этап своего обновления в условиях меняющихся политических процессов в стране [Дахин 2016]. После китайского направления кафедра истории НГЛУ намерена оформить японское направление в рамках зарубежного регионоведения. Благо, в инязе уже сформировался Японский культурный центр. Развитие регионоведения как направления подготовки бакалавров дало основу для создания в сентябре 2020 г. научно-исследовательской лаборатории под названием «Историческая компаративистика, регионоведение и развитие восточноазиатских территорий». Ее создание было вполне логичным шагом к развитию предыдущих усилий по повороту НГЛУ к Востоку. Своеобразным итогом работы вновь созданной лаборатории явилось проведение в мае 2021 г. международной научно-практической конференции «Влияние религиозного фактора на стабильное развитие и безопасность евразийских регионов: история и современность». НИЛ по исторической компаративистике призван всячески способствовать укреплению направления «Зарубежное регионоведение».

Проблематику зарубежного регионоведения применительно к практике своего университета поддержали доктор политических наук, профессор, директор ИМОМИ Нижегородского государственного университета им. Н.И. Лобачевского М.И. Рыхтик (Нижний Новгород), который выступил с докладом на тему «Зарубежное регионоведение: сложное настоящее и светлое будущее?»; доктор исторических наук, профессор Нижегородского государственного университета им. Н.И. Лобачевского О.А. Колобов и доктор политических наук, профессор Нижегородского государственного университета им. Н.И. Лобачевского C.A. Колобова (Нижний Новгород), которые в докладе «Базовые концепты политической регионалистики и их практическое значение для развития образования и науки в России» отметили новые вызовы глобальной регионализации современного мира и поляризации центров геополитического влияния, что создает запрос на переосмысление ряда базовых концептов политической регионалистики в интересах сохранения и развития отечественных школ науки и образования.

Заключение. Дискуссия показала, что отечественная политическая регионалистика прошла 30-летний путь становления в качестве самостоятельной 
субдисциплины политической науки. В настоящее время она находится в состоянии развития, признаками которого является банализация некоторых концептуально-методологических и исследовательских практик, побудивших ряд активных исследователей 1990-х - начала нулевых годов покинуть это поле исследований, новые концептуальные вызовы и запрос на обновление методов исследования альтернатив актуальной региональной политики, в т.ч. связанных с вопросами взаимосвязи муниципальной и региональной, региональной и федеральной, федеральной и международной политики в общем поле единой системы публичной власти России. К признакам развития субдисциплины относится также и массовое распространение региональных кейсов почти по всем иным субдисциплинам политической науки, которые формируют свои поля региональных политических исследований, создавая запрос на их интегральную концептуализацию со стороны политической регионалистики. Наконец, интеграция концептуально-исследовательского материала региональных политических исследований в различные образовательные программы высшего образования также обновляет предметную область политической регионалистики и создает запрос на концептуально-методологическое осмысление этого процесса.

\section{Список литературы}

Авдонин В.С., Баранов А.В., Дахин А.В. 2008. Политическая регионалистика в современной России: ретроспектива и перспектива становления. Политическая наука в России: проблемы, направления, школы (1990-2007). М.: РОССПЭН. С. 105-125.

Аджемоглу Д. Робинсон Д.А. 2001. Узкий коридор. Государства, общества и судьба свободы (пер. с англ.). М.: АСТ. 704 с.

Василевски Я. 2009. Политическая элита средней ступени: проблематика исследования (перевод с польск. А.А. Зотова). - Политическая экспертиза: ПОЛИТЭКС. Т. 5. № 2. С. 5-27.

Гельман В.Я. 2001. По ту сторону Садового кольца: опыт политической регионалистики России. - Полития. № 4. С. 65-94.

Гельман В., Рыженков С., Белокурова Е., Борисова Н. 2002. Автономия или контроль? Реформа местной власти в городах России. 1991-2001. СПб: Европейский университет в Санкт-Петербурге; Летний сад. 380 с.

Дахин А.В. 2015а. Региональная стратификация общества: глобальное и локальное в культуре, экономике, и политике. Часть 1. - Власть. № 10. С. 5-15.

Дахин А.В. 2015б. Региональная стратификация общества: глобальное и локальное в культуре, экономике, и политике. Часть 2. - Власть. № 11. С. 40-48.

Дахин А.В. 2016. Политическая регионалистика в России: На пути к устойчивой научной полноте. - Политическая наука. № 2. С. 132-163.

Иванов А.Г. 2017. Россия и Запад: конфликт интересов или новая холодная война? - Историческая и социально-образовательная мысль. Т. 9. № 5-2. С. 63-67.

Информационный бюллетень секиии политической регионалистики. Департамент политической науки НИУ ВШЭ. 2015-2019. Вып. 1-18. М.: ИД НИУ ВШЭ.

Исаев Б.А. 2013. Теория политических элит. - Введение в политическую теорию (под ред. Б.А. Исаева). Гл. 5. СПб: Питер.

Казаков М.А., Лысцев М.С. 2013. Политическое лидерство: сущность и проблемы реализации теоретических моделей в стратегии развития России. Регионология. № 1. С. 4-13.

Ковалев В.А. 2016. Российский кризис как вызов региональным политическим институтам (скандал с арестом губернатора Коми как пример институ- 
циональной слабости). - История и политика. Антикризисная стратегия: опыт и современность: материалы Х Международного симпозиума. 24-26 мая 2016 г. Н. Новгород: НИУ РАНХиГС.

Ковалев В.А. 2018. Издержки федерализма и административной вертикали России: попытка сравнения. - Политическая экспертиза: Политэкс. № 4. C. 104-121.

Кузьмин А.С., Мелвин Н.Дж., Нечаев В.Д. 2002. Региональные политические режимы в постсоветской России: опыт типологизации. - Полис. Политические исследования. № 3. С. 142-155.

Ледяев В. 2012. Социология власти. М.: ИД НИУ ВШЭ. 472 с.

Моляренко О. 2021. Местное самоуправление в России, или Хроники крайней власти. - Мир России. Социология. Этнография. № 1. С. 8-28.

Остром Э. 2010. Управляя общим: эволюция институтов коллективной деятельности (пер. с англ.). М.: ИРИСЭН; Мысль. 447 с.

Россия регионов: Трансформация политических режимов (под ред. В. Гельмана, С. Рыженкова, М. Бри). 2000. М.: Весь Мир. 376 с.

Туровский Р.Ф. 2009. Региональные политические режимы в России: к методологии анализа. - Полис. Политические исследования. № 2. С. 77-95.

Туровский Р.Ф. 2015а. Местное самоуправление в России и эволюция политического режима. - Pro пunc. № 1. С. 82-98.

Туровский Р.Ф. 2015б. Муниципальная политика. - Структурные трансформации и развитие отечественных школ политологии (под ред. О.В. ГаманГолутвиной). М.: Аспект Пресс. С. 216-242.

Туровский Р., Васеленко Е. 2019. Актуальное состояние и перспективы развития внутригородского местного самоуправления в больших городах. Регионология. Т. 27. № 1. С. 13-30.

Чирикова А., Ледяев В. 2017. Власть в малом российском городе. М.: ИД НИУ ВШЭ. 414 c.

Чирикова А. Ледяев В. 2020. Власть в моногороде: векторы перемен. Вестник Пермского университета. Политология. № 2. С. 111-127.

Elazar D.J. 1999. Political Science, Geography, and the Spatial Dimension of Politics. - Political Geography. Vol. 18. No. 8. P. 875-886.

Gel'man V. 2008. Out of the Frying Pan, into the Fire? Post-Soviet Regime Changes in Comparative Perspective. - International Political Science Review. Vol. 29. No. 2. P. 157-180.

Putnam R.D. 1988. Diplomacy and Domestic Politics: The Logic of Two-Level Games. - International Organization. Vol. 42. No. 3. P. 427-460.

Renshon S.A. 2000. Political Leadership as Social Capital: Governing in a Divided National Culture. - Political Psychology. Vol. 21. No. 1. P. 199-206. 
DAKHIN Andrey Vasil'evich, Dr.Sci. (Philos.), Professor of the Chair of History and Theory of State and Law, Nizhny Novgorod Institute of Management - the Branch of Russian Presidential Academy of National Economy and Public Administration (46 Gagarina Ave, Nizhny Novgorod, Russia,603009; nn9222@rambler.ru)

AVDONIN Vladimir Sergeevich, Dr.Sci. (Pol. Sci.), Leading Researcher at the Institute of Scientific Information on Social Sciences, Russian Academy of Sciences (3 Dmitriya Ul'yanova St, Moscow, Russia; avdoninvla@mail.ru)

\title{
REGIONAL POLITICAL STUDIES AND REGIONOLOGY IN RUSSIA: TRANSIT OF THEORETICAL APPROACHES TO REGIONAL POLITICAL PROCESS IN THE LIGHT OF INTERNATIONAL RELATIONS OF A REGION AND THE MUNICIPAL POLICY
}

\begin{abstract}
The article is an overview of the discussion dedicated to the $30^{\text {th }}$ anniversary of Russian regional political studies, which took place in Nizhny Novgorod on May 27, 2021. The problem field of the materials combines their own content of political regional studies, regional studies, as well as the content of studies of municipal politics and the content of international relations, tied to the study of international relations of the region. The authors pay the main attention to the fact that regional policy, as a rather isolated systemic formation, is squeezed between internal subsystems (municipalities) and external for them supersystems (federal policy of Russia, international relations). As a theoretical form of a holistic description of the structure of "subsystems - system - supersystems", the autors consider the concept of regional stratification of the political space, which allows concretizing the ranges and forms of communication "region - municipality», "region - federal center», "region - actors of international relations» in the context of the concept of a unified system of public authority in Russia.

Keywords: regional political studies, regional stratification of political space, regional public power, municipal public power, municipal capacity, regional political regime, political leadership, regional political elite
\end{abstract}

ИВАНОВ Олег Борисович - руководитель Центра урегулирования социальных конфликтов (143402, Россия, Московская обл., г. Красногорск, Ильинское ш., 1A; collegiamo@gmail.com)

\section{ИСПОЛЬЗОВАНИЕ МЕДИАЦИОННЫХ ТЕХНИК ПРИ УРЕГУЛИРОВАНИИ КОНФЛИКТОВ В ХОДЕ ИЗБИРАТЕЛЬНЫХ КАМПАНИЙ}

\begin{abstract}
Аннотация. Статья посвящена перспективам использования медиационных техник при урегулировании избирательных конфликтов и имеет практическую направленность. Избирательные конфликты сами по себе являются перспективной темой для исследования, поскольку их возникновение неизбежно при любой политической системе, предусматривающей проведение выборов. При этом в силу специфики таких конфликтов добиться даже частичного их урегулирования существующими правовыми механизмами не представляется возможным. В статье делается попытка проанализировать потенциал медиации в этом направлении.

Ключевые слова: выборы, конфликт, медиация, разрешение конфликта, избирательный процесс, избирательная кампания
\end{abstract}

Конфликт. Объективная реальность и опыт недавно прошедших избирательных кампаний настоятельно требуют решать следующие актуальные задачи: 